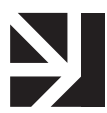

\title{
Taloustiede episteemisenä yhteisönä ja kamppailu asiantuntijuudesta
}

Teppo Eskelinen, dosentti, tutkija, Yhteiskuntatieteiden ja filosofian laitos, Jyväskylän yliopisto

Paul Jonker-Hoffrén,VTT, tutkija, sosiaalitieteiden laitos, Turun yliopisto

\begin{abstract}
Abstrakti
Artikkelissa tutkitaan taloustiedettä episteemisenä yhteisönä ja tämän episteemisen yhteisön käyttämiä retorisia keinoja rajojensa puolustamiseen. Episteemisen yhteisön teoria korostaa jaettuja metodologisia lähtökohtia ja arvolähtökohtia yhteisöjen koossapitävinä voimina, minkä lisäksi taloustiede on havaittu tutkimuksessa erityisen metodologisesti eristäytyneeksi. Artikkelissa eritellään taloustieteilijöiden episteemisen yhteisön suomalaisessa julkisuudessa käyttämiä retorisia strategioita sosiaalisesta mediasta kerätyn aineiston avulla. Aineistosta erottuvat strategiat ovat epäsymmetrinen näytön vaatiminen, auktoriteetin kieltäminen ja kaksoisstandardi.
\end{abstract}

\section{Johdanto}

Tutkimme tässä artikkelissa talousasiantuntijuuden ilmentämistä ja talousasiantuntijoiden ryhmän ylläpitämistä suomalaisessa keskustelussa analysoimalla prosessissa käytettyä retoriikkaa. Näkökulmana on valtavirran taloustieteilijöiden (tästä lähtien: taloustieteilijöiden) tulkitseminen episteemisenä yhteisönä eli episteemisesti osittain suljettuna asiantuntijoiden joukkona, jolla on myös laajempia yhteiskunnallisia pyrkimyksiä. Tällaisen yhteisön ylläpitäminen ei rajaudu tieteelliseen toimintaan. Asiantuntijuutta koskevien määrittelykamppailujen taustalla on yhteisöjen ylläpitämisen tarve.

Taloustieteilijöiden asemaa valtamediajulkisuudessa on selvitetty useissa viimeaikaisissa tutkimuksissa myös Suomessa. Esimerkiksi Timo Harjuniemi, 
Juha Herkman ja Markus Ojala (2015) toteavat taloustieteilijöiden olevan "kriisijulkisuuden rutiininomaisia lähteitä". Aapo Parviainen (2015) puolestaan on havainnut, että pankkiekonomistit saavat valtajulkisuudessa akateemisia ekonomisteja enemmän puhetilaa, josta he eivät joudu kamppailemaan. Tässä artikkelissa keskitymme ennen kaikkea sosiaalisen median julkisuuteen ja osittain tiedepoliittiseen julkisuuteen. Tutkimuskysymyksemme ei liity julkisuuden kykyyn valikoida "oikeita" asiantuntijoita formaalien tieteellisten kriteerien mielessä. Sen sijaan kysymme, minkälaisten retoristen strategioiden avulla episteeminen yhteisö määrittelee legitiimejä puhujia, tieteen ääntä, uskottavuutta ja asiantuntijuutta. Käytämme empiirisen aineiston tukena sekä talousretoriikan teoriaperinnettä että episteemisten yhteisöjen teoriaa.

\section{Taloustieteen asiantuntija-asema julkisuudessa}

Talousasiantuntijasta on tullut viime aikoina julkista yhteiskuntapoliittista keskustelua hallitseva hahmo. Siinä missä hyvinvointivaltion kultakaudella paradigmaattinen yhteiskuntatieteellinen asiantuntija oli sosiologi, on juuri taloustieteilijät nostettu nykyaikana rutiinikommentoijiksi ja näkyvimmiksi asiantuntijoiksi (esim. Kaidesoja 2016). Systemaattista tutkimusta eri asiantuntijoiden mediarooleista on kuitenkin tehty vähän.

Julkinen asiantuntija-asema ei selity pelkästään formaalilla asiantuntijuudella tai tieteellisillä meriiteillä. Siksi sitä ei myöskään voida analysoida ainoastaan tutkimalla julkisen keskustelun kykyä nostaa esiin tieteellisin kriteerein "parhaat" asiantuntijat. Julkiseen asiantuntija-asemaan valikoitumisessa on kyse laajemmasta kulttuurisesta ilmiöstä ja ulkotieteellisestä auktoriteettiasemasta. Tieteellisen vaikutusvallan realisoituminen edellyttää auktoriteettia ja institutionaalista asemaa, jotka ovat jossain mielessä tutkimusnäytöstä tai politiikkasuositusten toimivuudesta riippumattomia tai niitä "edeltäviä" (Hirschman \& Berman 2014, 801). Tätä auktoriteettiasemaa kuitenkin myös vahvistetaan korostamalla näennäisen neutraalia asiantuntijuutta ja eksaktin metodologian hallintaa.

Taloustieteilijöiden kasvanut painoarvo on erityisen huomionarvoista taloustieteellisten koulukuntakiistojen valossa. Taloustieteessä vallitsee lukuisten metodologisten perinteiden rinnakkaiselon sijaan asetelma, jossa 
on yksi hegemoninen tutkimusote ja lukuisia marginalisoituja haastajia. Uusklassinen taloustiede on luonteeltaan metodologisesti ja ontologisesti selvästi suljetumpaa kuin muut yhteiskuntatieteet. Muut yhteiskuntatieteet suorastaan ylpeilevät metodologisella pluralismilla. Esimerkiksi yhteiskuntatieteellisten tutkimusmenetelmien oppikirjassa Laadullinen tutkimus Pertti Alasuutari korostaa, että "mitä tahansa tekstikorpusta voi analysoida lukemattomin tavoin" (Alasuutari 2007, 27, monimuotoisuudesta ihmistieteissä ks. myös Raatikainen 2004, 87-111). Uusklassisen taloustieteen metodologis-ontologisen "kovan ytimen" hallinta edellyttää varsin pitkälle menevää matemaattista osaamista ja on siksi(kin) ulossulkevaa. Taloustieteilijöiden ammattikunta on myös globaalisti varsin yhtenäinen (Fourcade 2006). Ammatillinen sosiaalistuminen ja tietämisen tapojen normittuminen ylittää usein maiden ja kulttuurien rajat, mutta uusklassisen taloustieteen parissa tämä ilmiö on erityisen korostunut. Rajojen ylittäminen synnyttää poikkikansallisesti yhteneväisiä episteemisiä yhteisöjä (Vähämaa 2015, 209).

Uusklassista taloustiedettä haastavia koulukuntia eli niin sanottua heterodoksista taloustiedettä on lukuisia suuntauksia (Foldvary 1996; Lee 2009). Niiden parissa taloutta lähestytään metodologisesti ja/tai ontologisesti uusklassisesta otteesta poikkeavalla tavalla. Keskeinen ero on ontologisen tasapainoajattelun ja usein myös matemaattisen mallintamisen kritiikki. Uusklassinen taloustiede ei ole päätynyt taloustieteen hallitsevaksi suuntaukseksi konventionaalisten tieteenihanteiden mukaisilla keinoilla, kuten esimerkiksi tieteellisen kiistan ratkeamisella tai vaihtoehtoisen teorian sortumisella anomalioihin. Viimeisin laaja-alainen metodologinen kiista uusklassisen koulukunnan ja sen vastustajien välillä oli 1950-70-luvuilla käyty niin sanottu Cambridgen pääomakiista. Kiista ei ratkennut ainakaan uusklassisen taloustieteen eduksi. (Kiistasta ks. Cohen \& Harcourt 2003, laajemmin kiistan taustakysymyksistä ja merkityksestä Cohen 2010). Uusklassisen taloustieteen aseman muotoutumisessa ja puolustamisessa korostuvat varsinaisten demarkaatiokriteerien eli tieteen ja ei-tieteen (esimerkiksi valetieteet ja tiedettä popularisoivat tekstit) välisen rajanvedon (Nickles 2006) ohella "ulkotieteelliset" tekijät ja tieteen sosiaaliset käytännöt. Valtavirtaisen taloustieteen asemassa ei siis ole kyse yksinomaan parhaan argumentin ja tieteen itsekorjaavuuden periaatteista, vaan myös sosiaalisten ryhmien dynamiikasta. 
Uusklassinen taloustiede on viime vuosikymmeninä ottanut entistä selvemmin etäisyyttä heterodoksiseen taloustieteeseen ja yhteiskuntatieteeseen yleisesti. Tämä käy ilmi esimerkiksi taloustieteen erityisasemaa yhteiskuntatieteiden kentällä tutkineiden Fourcaden, Ollionin ja Alganin (2015, suomeksi ks. myös Suvanto 2016) analyysista. He erottavat neljä taloustieteen asemaan liittyvää erityispiirrettä. Näitä ovat aseman sulkeutuneisuus (insularity), aseman hierakkisuus suhteessa muihin yhteiskuntatieteisiin, siirtymä pois muihin yhteiskuntatieteisiin viittaamisesta ja orientaatio liikeelämän suuntaan sekä yhteiskunnallinen vaikutusvalta. Fourcaden, Ollionin ja Alganin (2015) mukaan taloustieteelle on yleisemminkin syntynyt tunne "luonnollisesta taipumuksesta asemaansa", mikä on seurausta oppialan hierarkkisesta luonteesta, suuresta markkinakysynnästä sen edustamalle osaamiselle erityisesti valta-asemassa olevien tahojen parissa ja ammattikunnan korkeasta palkkatasosta. Tämä yhteiskunnallisen paremmuuden asema ruokkii itsevarmuutta, joka kannustaa alaa pitämään kiinni vahvasta episteemisestä eristäytyneisyydestään (emt., 91).

\section{Episteemiset yhteisöt}

Episteemisellä yhteisöllä tarkoitetaan asiantuntijoiden verkostoa, jolla "on tunnistettua asiantuntijuutta tietyllä alueella ja jotka katsovat omaavansa poliittisesti relevanttia tietoa tuon alueen sisällä” (Haas 1992, 3). Peter M. Haasin (1992) jaottelun mukaan episteemisen yhteisön jäsenillä on 1) jaettuja normatiivisia ja periaatteellisia uskomuksia, jotka luovat arvopohjaisen logiikan yhteisön jäsenten yhteiskunnallista toimintaa ohjaavan arvoperustan, 2) metodologisista käsityksistä nousevia jaettuja käsityksiä maailmassa vaikuttavista kausaalisuhteista, 3) jaettuja sisäisesti määriteltyjä kriteerejä alaansa kuuluvan tiedon arvioinnille ja validoinnille sekä 4) jaettuja politiikkapyrkimyksiä. Uusklassiseen taloustieteeseen sovellettuna nämä tarkoittavat ennen kaikkea jaettua uskoa alan metodologiseen kovaan ytimeen, johon kuuluu metodologinen individualismi, tasapainousko ja optimaalisuus normatiivisena ideana sekä näihin nojaavat politiikkasuositukset. Uusklassisen metodologian sisäänrakennetut oletukset (vapaat ja rationaaliset markkinasubjektit, ongelmitta saatavilla oleva hinta-informaatio) saavat markkinoiden 
esteet vaikuttamaan luontevilta selityksiltä yhteiskunnallisiin ongelmiin. Tämän johdosta myös politiikkasuositukset keskittyvät usein markkinoiden avaamiseen.

Episteemiset yhteisöt levittävät erilaisia politiikkaideoita yhteiskunnallisten ongelmien määrittelyn, ratkaisukeinojen ja kehystävien paradigmojen mielessä. Tästä syystä on olennaista erottaa episteeminen yhteisö ja tieteenala. Episteeminen yhteisö on ideologisesti yhtenäisempi kuin kokonainen tieteenala. Tämä mahdollistaa yhteisön uskomusten kanssa yhteensopivan politiikan edistämisen (Hirschman \& Berman 2014, 784). Aiemmissa tutkimuksissa on havaittu, että politiikkaideoiden leviäminen ei ole niinkään seurausta niiden jäljittelystä mallin tai esimerkin mukaan kuin asiantuntija-asemaa koskevien kamppailujen kääntymisestä yhden episteemisen yhteisön voitoksi (Kogut \& MacPherson 2004). Tämä havainto pätee erityisesti taloustieteeseen. Politiikkasuositusten rakentumisen on katsottu selittyvän erityisesti taloustieteilijöiden ideoiden koherenssilla (Chwieroth 2007). Taloustietelijöiden ympärillä vaikuttaa tyypillisesti myös keskeiset politiikkasuositukset jakava akateemista taloustiedettä laajempi "ajatusyhteisö" (Mirowski \& Plehwe 2008). Asiantuntijuudella viitataan tässä yhteydessä statukseen: kenen arvioita tai osittain subjektiivisia käsityksiä pidetään arvokkaana ja kenen voi olettaa puhuvan legitiimisti tieteellisen tutkimuksen äänellä.

Sisäryhmän rajojen ylläpitämistä on tutkittu ennen kaikkea kielen ja viestinnän tutkimuksessa sekä jossain määrin sosiologiassa ja sosiaalipsykologiassa (Scheepers ym. 2006; Tsoukala 2008; Yardi \& boyd 2010). Tutkimuksessa tehtyjen havaintojen mukaan käsitys tiedosta perustuu aina osittain ryhmäjäsenyyksiin. Vertaisryhmän uskottavana pitämät uskomukset käsitetään helpommin tiedoksi, minkä vuoksi tällaiset ryhmät aina tuottavat ja ylläpitävät omia sosiaalisia epistemologioitaan (Vähämaa \& West 2014). Jossain määrin koulukuntien ja niihin liittyvien vertaisryhmien muodostuminen on toki luonnollista ja väistämätöntä, mutta jos ryhmä on episteemisesti hyvin suljettu, se ei välttämättä missään vaiheessa käsittele kilpailevien paradigmojen tuottamia haasteita ja siten kehity. Taloustieteen tapauksessa on esimerkiksi havaittu, että sen julkaisuissa viitataan erittäin vähän muiden yhteiskuntatieteiden tuloksiin (Fourcade, Ollion \& Algan 2015, 102).

Taloustiedettä (uusklassisessa mielessä) voidaan tutkia tällaisena asiantuntijuudesta kamppailevana, rajojaan hallitsevana yhteisönä. Taloustieteen 
retoriikan tutkimuksessa on havaittu, että taloustiede perustuu tieteellisten käytäntöjen ohella uskonkappaleisiin, hypoteettisiin ajatuskokeisiin ja kamppailuun auktoriteettiasemasta (McCloskey 1998, 25, 102). ${ }^{3}$ Retorinen tarkastelutapa korostaa perinteisistä tieteenihanteista poiketen konstruktiivisuutta ja retoriikan ulkotieteellisyyttä. Asiantuntijuuden retorisessa rakentumisessa on kyse erityisesti sisäryhmän solidaarisuuden ja jaetun identiteetin hallinnasta. Tämä poikkeaa sellaisista formaaleista käytännöistä, kuten tieteellisestä statuksesta tai vertaisarvioinnissa, samoin kuin tavallisimmista pyrkimyksistä määritellä asiantuntijuutta, joissa korostuvat metakognitiiviset taidot, kuten suuntautuminen uusien haasteiden ottamiseen ja jatkuvaan osaamisen kehittämiseen (Hakkarainen ym. 2004) tai kykyyn valikoida oleellista informaatiota (Lehtinen \& Palonen 2011, 27, 30).

Julkisuudessa käytävien asiantuntijuuskamppailujen tutkimuksessa on huomattava, että julkisuuksia on monia ja ne muodostuvat erilaisissa prosesseissa. Julkisuudet eivät välttämättä ole jatkuvia ja vakaita, vaan ne voivat olla väliaikaisia (Kolehmainen \& Rättilä 2008, 4). Julkisuus on "nyky-yhteiskuntien teatteria, jossa poliittista osallistumista toteutetaan puhuen" (Fraser 2009, 9). "Julkisuutta" ei tule ymmärtää tieteelle ulkoisena piirinä. Tieteellinen ja julkinen keskustelu sekoittuvat enemmän kuin tieteensisäisiin vertaiskritiikin ja metodologian kysymyksiin keskittyvä klassinen tieteenihanne olettaa (Myers 2003). Siksi erityisesti tieteenalaa koskevilla julkisilla keskusteluilla on merkitystä myös tiedeyhteisön sisäisten käytäntöjen määräytymisessä. Todellisuuden ja diskursiivisten käytäntöjen välinen vuorovaikutussuhde on kaksisuuntainen: diskursiiviset kamppailut aina myös vaikuttavat todellisuuteen (Chouliaraki \& Fairclough 1999, 4). Tiedettä koskevat julkiset kiistat voivat vaikuttaa tieteen käytäntöihin (esim. Stewart 2008).

Tieteestä puhuttaessa ilmeisin julkisuuden muoto on tieteenalojen sisäinen julkisuus. Tämä tarkoittaa "perinteisiä" tieteellisen asiantuntijuuden määrittelyn foorumeja, kuten vertaisarvioidut journaalit tai julkiset tarkastustilaisuudet. Jokaisella tieteenalalla käydään jatkuvaa sisäistä keskustelua tällaisilla foorumeilla. Kuten todettua, asiantuntijuuskamppailut ulottuvat kuitenkin myös formaalien tieteellisten käytäntöjen ulkopuolelle. 


\section{Aineisto ja metodologia}

Ensisijainen tutkimusaineistomme on kerätty sosiaalisesta mediasta. Tämän lisäksi olemme keränneet taustoittavaksi toissijaiseksi aineistoksi tiedepoliittisista julkaisuista koostuvan aineiston. Toissijainen aineisto toimii tutkimuksessa taustatietona ja vertailukohtana, jonka avulla hahmotamme "perinteisessä" tiedejulkisuudessa käytävää keskustelua voidaksemme tuoda myöhemmin esiin sosiaalisen median erityispiirteitä. Aineisto koostuu Tieteessä tapahtuu ja Tiedepolitiikka -lehtien artikkeleista vuosikymmenen alusta (2010) toukokuuhun 2016. Aineisto kattoi 65 lehteä, jotka edustivat kattavaa otosta kotimaiseen tiedekeskusteluun. Näissä lehdissä oli yhteensä noin 400 kirjoitusta.

Sosiaalisella medialla (tästä eteenpäin: some) viittaamme laajasti uusiin ja interaktiivisiin verkkomedian muotoihin (blogit, Facebook, Twitter, keskustelupalstat, yms.). Ne voivat olla kokonaan tai osittain avoimia. Nopeasti muuttuva sosiaalinen media luo jatkuvasti uusia, joustavia ja tilapäisiä julkisuuksia. Näillä julkisuuksilla on kuitenkin samanlaisia funktioita kuin millä tahansa julkisuuksilla: ne korostavat joitakin ääniä ja marginalisoivat toisia. Sosiaalisen median erikoispiirre on portinvartijoiden puute, minkä johdosta kamppailut äänivallasta liittyvät suoremmin käytettyyn retoriikkaan ja edellä kuvattuihin ryhmäytymistä koskeviin ilmiöihin.

Sosiaalisessa mediassa on viime vuosina esiintynyt runsaasti poliittista keskustelua, johon kuuluu myös asiantuntijoiden keskustelua ja kamppailua asiantuntijastatuksesta. Sosiaalisen median poliittista asemaa on tutkittu runsaasti aiemmassa tutkimuksessa (esim. Shirky 2011). Tiedekeskustelu on ainakin toistaiseksi ollut sosiaalisessa mediassa vähäisempää. Tämä voi johtua esimerkiksi siitä, että tieteellä on vahvoja perinteisiä julkisuuksia. Sosiaalisen median vilkas talouskeskustelu on tästä kuitenkin selvä poikkeus. Jo yksittäisten debattien tarkastelu osoittaa, että sosiaalisessa mediassa käydään jatkuvaa kamppailua legitiimistä talousasiantuntijuudesta. Sosiaalinen media on kaukana perinteisestä tieteenalojen sisäisestä julkisuudesta avoimuutensa vuoksi. Lisäksi se on avoin kamppailujen foorumi, jossa kiistat näkyvät selkeämmin ja usein myös eskaloituvat. Sitä voidaan näin ollen lähestyä paitsi uutena, myös kamppailujen ja retoriikan näkökulmasta kiinnostavana julkisuutena.

Tässä artikkelissa tarkastelemme talousasiantuntijuudesta käytävää määrittelykamppailua Twitterissä, koska se muodostaa avoimen ja julkisen 
keskustelutilan. Twitter julkisuutena on olennainen, koska se ei rajoita keskustelujen osallistujia, kuten esimerkiksi "kavereille" rajattu Facebook, vaan kuka tahansa Twitter-käyttäjä voi periaatteessa ryhtyä haastamaan muita keskustelijoita. Jätimmekin Facebookin aineiston ulkopuolelle, koska palvelu vaatii rekisteröitymistä, eikä sieltä kerättyä aineistoa voida pitää täysin julkisena. Havaitsimme monia aiheen kannalta relevantteja keskusteluita käytävän myös esimerkiksi erilaisten uutisten kommenteissa ja muilla kommenttipalstoilla. Olemme silti jättäneet nämä keskustelut aineistomme ulkopuolelle aineistonkeruun haasteiden vuoksi. Pääasiallisena haasteena on se, että monet uutisartikkelit ovat maksumuurin takana eli ne ovat alun perin saatavilla vain tilaajille tai siirtyvät pian julkaisun jälkeen maksumuurin taakse. Uutisartikkelien tekninen rakenne hankaloittaa myös aineistonkeruuta. Uutisartikkeleilla on usein kommenttiosio, josta aineiston kerääminen on vaikeaa, sillä kommentit jakautuvat useammille uutisartikkelin sivuille.

Sosiaalisen median erityispiirre on sen kyky kerätä ja tallettaa "luonnollisesti kerääntyvää ja käyttäjien luomaa dataa" (Edwards ym. 2013). Twitteriä on pidetty metodologisesti kiinnostavana julkisuutena arkistoituvan datan suuren volyymin takia. Sitä käytetäänkin runsaasti niin sanottuun datan louhintaan perustuvassa tutkimuksessa. Niin sanottujen Big Data -menetelmien tarkoituksena on kerätä miljoonia twiittejä ja analysoida niitä erikoistuneella ohjelmistolla. Suuria Twitter-aineistoja on käytetty ennustamaan esimerkiksi influenssan leviämistä (Culotta 2010). Myös tämän artikkelin aihepiirin kannalta Twitter on kiinnostava tutkimuskohde käyttäjien luoman datan "luonnollisen kerääntymisen" vuoksi, vaikka aineiston koko onkin selvästi pienempi kuin Big Data -menetelmiä käyttävässä tutkimuksessa.

Tarkastelemme some-aineistoa spontaanien keskusteluiden joukkona. Kokosimme aineiston käyttämällä talousasiantuntijuuteen liittyviä avainsanoja. Käytimme aineistonkeruussa kahta strategiaa. Ensimmäinen oli uutisissa esillä olleiden termien paikantaminen. Tärkein esimerkki tästä on sana "huippuekonomisti", joka monet uutislähteet käyttävät Suomessa vierailevista ulkomaalaisista taloustieteilijöistä. Myös esimerkiksi avainsanaa "talousviisaat" käytetään uutisartikkeleissa usein. Toinen strategia oli keskustelujen suora paikantaminen. Tyypillinen esimerkki viimeaikaisesta talousasiantuntijuuteen liittyvästä keskustelusta on Laura Lindstedtin kantaaottavan Finlandia-palkintopuheen jälkeen versonut julkinen keskustelu. Strategian 
avulla löydettiin useita retoristen strategioiden tutkimisen näkökulmasta relevanttia keskustelua. Yksittäiset Twitter-kommentit on jätetty aineiston ulkopuolelle, koska tarkoituksenamme on tutkia keskusteluja. Twitteraineistossamme on yhteensä noin 750 twiittiä. Aineiston varhaisimmat twiitit ovat vuodelta 2013, mutta valtaosa on vuosilta 2015-16. Kokonsa vuoksi aineistoa ei voida pitää varsinaisena "isona datana", jonka analyysi perustuu aineiston massiiviseen kokoon, vaan pikemmin "ison datan" näytteenä.

On syytä tiedostaa käyttämämme aineistonkeruumenetelmän rajoitteet. Koska Twitter on "nopea” keskustelutyökalu, käytetty kirjoitustyyli on usein hyvin suoraa ja merkkimäärärajoitusten vuoksi nyanssit usein vähäisiä ja vastaukset epätarkkoja. Sanojen lyhenteet ovat Twitterissä yleistä ja lyhenteet voivat jäädä helposti hakujen ulkopuolelle. Varsin yleinen esimerkki on ilmaus "tal.tiet", mikä tarkoittaa ilmausta "taloustiede" tai jotain sanan muuta taivutusmuotoa. Keskustelussa saatetaan myös käyttää ad hoc -lyhenteitä tai muita merkitsijöitä. Aineiston rajoituksiin kuuluu myös, että se ei edusta "puhdasta" datan louhintaa, koska twiittejä ei ole kerätty automatisoidusti. Toisaalta puhdasoppinen Big Data -menetelmä (esim. Analysis with Programming 2014) ei sopisi tämän artikkelin tarpeisiin, koska tällöin aineisto ei koostuisi kokonaisista keskusteluista vaan ainoastaan tietyn avainsanan sisältävistä twiiteistä.

Analyysi osoitti aineiston olevan varsin saturoitunut: uudet keskustelut toistivat samanlaisia rakenteita (Eskola \& Suoranta 1998, 62-63). Toki koskaan ei voida olla varmoja siitä, etteikö aineiston kasvu voisi tuoda lisätietoa (Tuomi \& Sarajärvi 2002, 90). Some-aineistossa jo kohtuullisen kokoinen joukko uusia aktiivisia keskustelijoita voi muuttaa aineiston luonnetta. Tämän vuoksi tarkastelemiamme keskusteluja tulee pitää "tilapäisenä julkisuutena”. Kvalitatiiviselle aineistolle tyypillisesti aineistossa on myös analyysin kannalta hyödytöntä dataa. Tällaista esiintyy erityisesti nopeissa keskusteluissa, joissa on jälkikäteen vaikeasti ymmärrettäviä kommentteja. Keskustelutyyli myös vaihtelee runsaasti erilaisten tekijöiden mukaisesti. Kiivaimmat keskustelut käydään usein myöhään illalla.

Twitter-keskustelujen analyysissa on otettava huomioon myös keskustelujen luonne. Ne muistuttavat rihmastoa tai juuria: yksi twiitti voi aiheuttaa hyvin haarailevan ja epälineaarisen keskustelun. Myöhempi vastaus ensimmäiseen twiittiin voi hyvin poikia vastauksia eri vastausketjuun ja toisinpäin. 
Usein keskustelua käydään myös pelkästään jakamalla linkkejä. Viestien pilkkominen vaikeuttaa keskustelun hahmottamista entisestään ja lisää sen todennäköisyyttä, että joku vastaa väärään viestiin. Rihmastomainen keskustelu voi liikkua nopeasti kauas alkuperäisestä aiheesta. Tästä syystä olemme poimineet analyysissamme pätkiä keskusteluista yksittäisten twiittien sijaan.

Aineistosta erottuu hallitseva aktiivikeskustelijoiden joukko, joka debatoi erityisesti taloudesta kiinnostuneiden ei-taloustieteilijöiden ja heterodoksisten suuntausten edustajien kanssa. Joukon ydin koostuu akateemisista ekonomisteista sekä tutkimuslaitosten ja lobbausorganisaatioiden ekonomisteista. Tämän joukon puoleensa vetämänä keskusteluihin osallistuu jonkinlaisina kannustajina poliitikkojen avustajia ja muita Twitterin käyttäjiä, joista osa toimii nimellään ja osa nimimerkin turvin. Näiden toimijoiden muodostama samanmielisten yhteisö näyttäytyy uusklassisen asiantuntijuuden puolustajina. Yhteisön rakenne ja eetos vastaa varsin pitkälti Mirowskin ja Plehwen (2008) uusliberalismin kehityksen tutkimuksessaan kuvaamaa laajempaa "ajatusyhteisöä", johon kuuluu taloustietelijöiden lisäksi lobbareita, liikeelämän toimijoita ja muita vaikutusvaltaisia toimijoita. Aineisto osoittaa myös selvää ryhmäytymistä asiantuntijayhteisön ylläpidon mekanismina (Vähämaa \& West 2014): keskustelut luovat nopeasti ryhmän yhteenkuuluvuutta ja solidaarisuutta jonkinlaisen asiantuntijoiden ytimen ympärille. Tämä näkyy ryhmän jäsenten tavassa mobilisoitua nopeasti yhteiseen asiaan nimenomaan taloustieteen sovellusalojen, metodologian ja asiantuntijuuden kysymyksissä.

Analysoimme yllä kuvattua aineistoa aluksi aineistolähtöisen sisällönanalyysin keinoin (ks. Tuomi \& Sarajärvi 2002, 105-116). Olemme luokitelleet ja koodanneet aineiston keskustelujen tyylin, muodon ja dynamiikan hahmottamiseksi. Some-aineistosta voidaan tunnistaa kahdenlaisia typlejä: uutisartikkelin jakamisesta Twitterissä syntyvät keskustelut ja twiitin yhteydessä syntyvät keskustelut. Näistä edellinen sisältää myös keskusteluja uutisista, joita ei välttämättä ole samassa yhteydessä jaettu Twitterissä. Aineistossa esiintyviä muotoja ovat keskustelu (dialogi), vastakkainasettelu ja hyökkäys. Dialogiset keskustelut ovat aineistossa harvinaisia. Suurin osa aineiston keskusteluista on vastakkainasetteluja eli keskusteluja, joissa jyrkästi eri mieltä olevat tahot yrittävät vakuuttaa toisen näiden aseman harhoista. Hyökkäys on tyyliltään aggressiivisempi ja esiintyy aineistossa yleensä silloin, kun taloustieteen oppeja pyritän kyseenalaistamaan. Nämä edustavat pienempää osaa 
aineistosta, mutta tuovat episteemisen yhteisön perustaa havainnollisimmin esiin. Dynamiikka viittaa siihen, miten sekä keskustelu että keskustelijoiden määrää kehittyy. Tarkastelemiemme Twitter-keskustelujen dynamiikka on useimmiten rihmastomainen.

Sisällönanalyysin ohella käytimme aineiston analyysissa retoriikka-analyysin menetelmää (esim. Perelman 1996). Sisällönanalyysia käytettiin luokittelemaan keskusteluja edellä kuvatulla tavalla. Retoriikka-analyysi toteutettiin katsomalla, millaisia retorisia kuvioita puhujat käyttivät vastapuhujan suhteeseen. Keskustelustrategioiden tunnistaminen edellyttää luokittelun ja koodauksen kaltaisten sisällönanalyysin työkalujen avulla tunnistettujen keskustelustrategioiden sisältämän argumentaation analyysia. Retoriikan analyysissa tutkimme erityisesti argumentoinnin edellytyksiin ja auktoriteettiin viittaavia teemoja. Jo Aristoteleen retoriikasta asti on ollut tapana erottaa puhujan auktoriteetti / uskottavuus (eetos) puheen formaalista johdonmukaisuudesta (logos). Tässä yhteydessä olemme erityisen kiinnostuneita siitä, miten auktoriteetista kamppaillaan nimenomaan ryhmänä ja miten auktoriteetti- ja argumenttikamppailut limittyvät ryhmään.

Analysoimme aineistossa esiintyviä keskustelustrategioita erityisesti siitä näkökulmasta, miten niissä suojellaan ja uusinnetaan taloustieteilijöiden episteemistä yhteisöä ja talousasiantuntijuutta. Keskustelustrategiat kuvaillaan alla tarkemmin esimerkkien avulla. Esitämme strategioiden esittelyn yhteydessä myös näyte-esimerkkejä aineistosta. Strategian käsite viittaa tässä yhteydessä keskustelutapoihin ja argumentaation kategorioihin. Emme toisin sanoen tarkoita keskustelustrategialla strategiaa suunnitelmallisuuden tai koordinoidun toiminnan mielessä. Yhteistä keskustelustrategioille on se, että niillä ajetaan muut keskustelijat jollakin tavalla pois keskustelemasta taloustieteestä ja sen heikoista pisteistä. Tämä voi tapahtua joko vaatimalla, että keskustelija tutustuu johonkin teoriaan ennen kuin hän tulee keskustelemaan, tai sitten vaatimalla "oikeanlaista" näyttöä keskustelijan väitteen tueksi. Käytettyjä keskustelustrategoita voidaan tulkita niin, että niiden tavoitteena on lopettaa keskustelu taloustieteestä. Vaikka aineistossa esiintyi erilaisia tyylejä ja muotoja, tulivat samat keskustelustrategiat jatkuvasti esiin.

Olemme jättäneet analyysista pois kaikki twiittaajien tunnistetiedot lukuun ottamatta asemaa tai ammatillista statusta koskevat kuvaukset ("taloustietelijä", "humanisti", "taloudellisen tutkimuslaitoksen tutkija”, yms.). Tämä ei johdu 
niinkään tutkimuseettisistä syistä kuin pyrkimyksestä välttää analyysin tarpeetonta henkilöimistä. Twitter-viestit ovat julkisia ja siten avoimia siinä missä mikä tahansa internetin sisältö. Alkuperäiset twiitit ovat myös periaatteessa löydettävissä, joten anonymisointi ei takaa varmaa anonymiteettiä. Keskustelujen henkilöiminen on nähdäksemme tarpeetonta retoristen strategioiden tutkimisen näkökulmasta. Mainitsemme kuitenkin nimeltä aineiston ulkopuolisia julkisuuden henkilöitä tilanteissa, joissa tämä on keskustelun kontekstin selventämiseksi välttämätöntä.

\section{Löydökset}

Useat tiedepoliittisten lehtien artikkeleista koostuvan sekundaariaineiston sisältämät artikkelit toistivat aiemmassa tutkimuksessa tehtyjä huomioita "taloustieteen imperialismista" (käsitteen merkityksestä ks. esim. Mäki 2009; Fine 2002). Aineiston taloutta käsittelevät artikkelit voidaan jakaa väljästi kahteen pääteemaan. Ensimmäinen teema liittyy taloustieteellisen metodologian sovellettavuuteen. Tällaiset artikkelit edustavat pyrkimystä ulottaa taloustieteen metodologia muiden tieteiden perinteiselle kentälle tai suositella sitä muiden tieteiden käyttöön. Toisaalta taloustieteellisen metodologian rajoja käsiteltiin myös useita artikkeleita käsittäneessä keskustelussa, joka koski ennustamisen mahdollisuutta taloustieteessä. Tämä vahvistaa havaintoja taloustieteen pyrkimyksestä jonkinlaiseen metodologiseen imperialismiin eli pyrkimykseen saada muut tieteet omaksumaan taloustieteen metodologiset lähtökohdat (Nik-Khah \& van Horn 2012; Fourcade, Ollion \& Algan 2015, 94).

Toinen teema on taloustieteilijöiden pyrkimys antaa poliittisia neuvoja korostaen taloustieteellistä lähestymistapaa. Tällaisissa puheenvuoroissa esimerkiksi suositeltiin tekemään työttömyydestä "inhottavampaa” työvoiman tarjonnan edistämiseksi sekä vastustettiin maksutonta koulutusta. Tyypillisesti tällaisissa artikkeleissa taloustieteilijä esittää itsensä ikävän mutta välttämättömän uutisen tuojana. Tätä voidaan tulkita "aidomman" asiantuntijuuden representoimiseksi: muiden tieteiden edustajat eivät halua mukavuussyistä kohdata ekonomistin tuomia "uutisia". Esimerkistä käy vaikkapa seuraava lainaus: "Kestävyysvaje on kuitenkin pakko hoitaa, muuten joudumme räjähtävän julkisen velan kierteeseen. [...] Toivon, että filosofit olisivat tässä 
keskustelussa aktiivisesti mukana, muutenkin kuin taivastelemassa selkäydinvasemmistolaisuuden pohjalta meidän uusklassisten virkamiestaloustieteilijöiden kovuutta" (Vartiainen 2014, 36).

Tiedepoliittisten lehtien keskustelu jää laajemmassa aineistossa yksittäisiksi teksteiksi. Kun aineistoa verrataan some-aineistoon, käy ilmeiseksi, että asiantuntijuuskamppailut keskittyvät nykyisin sosiaalisen median julkisuuteen perinteisemmän tieteellisen julkisuuden sijaan. Sosiaalista mediaa luonnehtii avoin osallistuminen perinteisten tieteellisten keskustelujen kriteerien tai perinteiselle mediajulkisuudelle ominaisten puheen hierarkioiden sijaan. Sosiaalisen median toimintalogiikka poikkeaa selvästi tieteen keskustelu- ja kritiikkikäytännöistä. Toisaalta myös sosiaalisessa mediassa keskustelua käyvät voittopuoleisesti akateemiset tahot, jotka ovat ikään kuin siirtäneet keskustelun uudelle foorumille. Tässä mielessä kyse ei ole tyypillisestä "kansalaiskeskustelusta". Sosiaaliseen mediaan siirtymisen myötä keskusteluissa on käytetty rutiininomaisesti argumentatiivisia strategioita, joita ei pidettäisi hyvän tieteellisen käytännön mukaisina. Somessa vallitseva sosiaalinen toimintakoodi on erilainen kuin akateemisessa maailmassa. Twitterissä onkin myös talousaiheiden ympärillä runsaasti keskustelua, jota ei sävynsä puolesta voi luonnehtia asia-argumentaatioksi.

Retorinen kamppailu talousasiantuntijuudesta koostuu aineiston perusteella kolmesta keskeisestä elementistä. Ensinnäkin siitä, kenellä on ylipäänsä "lupa" tai legitiimi asema puhua taloudesta, käydään jatkuvaa kamppailua. Toiseksi toisten puhujien asiantuntijuutta pyritään jatkuvasti delegitimoimaan. Kolmanneksi hegemonista talousasiantuntijuutta haastavaa keskustelua pyritään ohjaamaan pois alkuperäisestä aiheesta. Toisinaan delegitimointi ja muut retoriset keinot esiintyvät yhtäaikaisesti. Tällöinkin keinojen tärkein ominaisuus on määritellä, ketkä ovat legitiimejä talousasiantuntijoita ja ketkä eivät. Uutismediassa on tuotu esiin, että kyseinen prosessi on ollut sosiaalisessa mediassa luonteeltaan hyökkäävää (esim. Helsingin Sanomat 2015).

Asia-argumentaation puuttuminen ja keskustelutapojen hyökkäävyys tulee esiin monilla eri tavoilla. Twitter-keskusteluissa nähdään usein tahallisen oloista värinymmärtämistä tai sanojen suuhun laittamista. Tähän joskus myös reagoidaan. Esimerkiksi voidaan nostaa viesti, joka liittyy alun perin kuluttajien rationaalisuutta käsitelleeseen keskusteluun: 
"Minä en ole puhunut hermostoista, joten älä laita sanoja suuhuni, kiitos."

Tiettyjen keskustelujen yhteydessä voitiin havaita usein ad hominem -argumentteja, jotka on joskus esitetty sarkasmin muodossa. Huumoria on vaikeaa välittää sosiaalisessa mediassa. Humoristisia viestejä usein kuitenkin tulkitaan kirjoittajan tarkoituksen vastaisella tavalla.

Yksi keskusteluissa näkyvä retorinen strategia on niin sanottu red herring eli harhaanjohtavan virheen argumentaatiotapa. Käytännössä strategia merkitsee keskustelun tietoista ohjaamista pois aiheesta. Tätä keskustelutapaa esiintyy aineistossa tilanteissa, joissa asiantuntijuutta haastetaan. Twitterin merkkimäärärajoitukset (140 merkkiä) tekevät tämän strategian vastustamisesta vaikeaa, koska keskusteluissa vastataan yleensä vain viimeiseen viestiin. Seuraavat twiitit esiintyivät keskusteluissa, jossa keskustelu erkaantui kauemmas alkuperäisestä aiheesta.

Humanisti: "Mitään en ole väistellyt, vaikka hienon joukkueen kanssa mua tässä lynkkaillaan!"

Puhuja 1: "Uhriutuminen ei auta jos väitteet ovat perustelemattomia ja et halua vastata kysymyksiin."

Humanisti: "Mihin kysymyksiin en ole vastannut tarkalleen? En uhriudu, tässä on aika iso joukkue mua teilaamassa."

Puhuja 1: "Puhut koko ajan isosta joukosta lynkkaamassa sua. Eikö se ole uhriutumista?"

Puhuja 2: "Kukaan ei ole lynkkaamassa. Moni vain haluaa saada perusteita väitteillesi. \#popcorn"

Humanisti: "Twitter ei ole perustelemisen paikka, blogissani käsittelin kaiken olennaisen [...] tekstistä.” 
Humanistin ensimmäinen twiitti käsitteli sitä, että hänen lukukausimaksuja käsitellyttä kirjoitustaan vastaan hyökättiin neljän miehen voimin, joista suuri osa oli kohtuullisen merkittävässä yhteiskunnallisessa asemassa, toisin kuin humanisti itse. Keskustelussa esiintyy strategia, jossa keskustelua ajetaan pois itse aiheesta jonkinlaiseen metakeskusteluun. Tällaiset "jatkokeskustelut" eivät yleensä ole erityisen asiapitoisia ja keskustelun saaminen takaisin raiteille on vaikeaa (vaikka tässäkin tapauksessa humanisti sitä yritti). Logiikka esiintyy myös seuraavissa esimerkeissä:

Taloustieteilijä: "Olen toistuvasti yrittänyt usuttaa sinua perehtymään asia-argumentteihin kirjallisuusviitteiden avulla."

Puhuja: "Hmm, erikoista. Linkität perusteoksiin, kun kysyin, mikä CJE:ssä julkaistuissa wage-led-argumenteissa pielessä?”

Taloustieteilijä: "Oletko sitten tutustunut jo perusoppikirjoihin?"

Puhuja: "Erikoista välttelyä. Yrität osoittaa, etten ole asiantuntija? Mitä merkitystä kysymykseni kannalta?"

Taloustieteilijä: "Yritän kohteliaimmin tuoda esiin, että vaadit väitt. kanssasi asioista joihin et ole viitsinyt perehtyä"

Tässä tapauksessa harhaanjohtavan virheen strategia toimii siten, että taloustieteilijä yrittää saada toisen puhumaan perusoppikirjoista sen sijaan, että vastaisi kysymykseen. Harhaanjohtavan virheen argumentti voi myös olla varsin absurdi:

”En osaa myöskään soittaa kitaraa saati pianoa. Olette kaikinpuolin ylivertaisia."

\section{Todistustaakka ja näytön vaatiminen}

Seuraavaksi esittelemme havaitsemiamme retorisia strategioita, jotka liittyvät suoraan asiantuntijuuden puolustamiseen. Ensimmäinen aineistosta erottuva 
päästrategia on epätasapainoinen näytön vaatiminen. Tällä tarkoitamme, että keskustelussa taloustieteilijät vaativat todisteita väitteistä painotetusti taustan perusteella. Kriittisen kommentin kirjoittajan tausta ei-taloustieteilijänä johtaa pyrkimykseen vierittää kirjoittajalle suuri todistustaakka. Tämän retorisen strategian tarkoitus ei ole edistää keskustelua, vaan osoittaa, että toinen osapuoli ei ole pätevä puhumaan aiheesta, koska ei hallitse aiheen hyväksyttävää käsittelytapaa. Hyvä esimerkki tästä on seuraava twiitti, joka esiintyi keskustelussa kuluttajan haluista. Keskustelun alussa puhuttiin onko kuluttaja rationaalinen taloustieteen tarkoittamassa merkityksessä. Keskustelu lähti kuitenkin pian raiteilta, sillä toinen keskustelija jatkuvasti esitti "tarkentavia" kysymyksiä, jotka eivät liittyneet alkuperäiseen keskusteluun rationaalisuudesta taloustieteessä.

"Tiedostamattomat prosessit" hyödyllinen lähtökohta tieteelliselle mallinnukselle. Onko tiedossa mitä ne ovat?

Tässä twiitissä tulee esiin sekä käytetty retorinen strategia että se, millainen vastaus olisi hyväksyttävä (so. tieteellinen mallinnus). Myöhemmin keskustelussa toinen keskustelija pilkkaa toisen keskustelijan argumentteja toteamalla, että [aivojen ulkopuolella tiedostetut prosessit ovat] "Oivallista science fiction materiaalia”.

Tästä retorisesta strategiasta on myös syvällisempi variaatio, joka osoittaa havainnollisesti talouden tutkimisen epistemologiaan liittyvät näkemyserot. Ensimmäinen esimerkki variaatiosta liittyy pitkään keskusteluketjuun lukukausimaksuista. Äänessä oli lukukausimaksuja vastustava kielitieteilijä ja joukko maksuja puolustavia taloustieteilijöitä. Jossain vaiheessa keskustelua kielitieteilijää vaadittiin esittämään tietoa siitä, että lukukausimaksujen puoltavan kirjoittajan näkemykset eivät edusta taloustieteen konsensusta:

"Oliko sinulla linkit jossain blogissa tai muuten nähtävillä?”

Vaikka tässä keskustelussa tapahtui jonkin verran sekaannusta sen suhteen, mihin kielitieteilijä reagoi, oli keskustelun jatko olennainen retorisen strategian kannalta. Eri twiittien ketjussa kommentoitiin, että jos joku ajatus kuuluu 
taloustieteen konsensukseen, kirjallisuusviitteitä ei tarvita:

"Kaikki minun kirjoituksessani olevat asiat ovat oppikirjatason kamaa, jonka kaikki ekonomistit tietävät."

Tämä tiivistää hyvin ensimmäisen havaitsemamme retorisen strategian: jos jokin näkemys ei kuulu (tietyn joukon mukaan) taloustieteen konsensukseen, kritisoijan tulee esittää näyttöä siitä, että konsensus on väärässä. Usein näissä keskusteluissa vaaditaan tieteellistä tutkimusnäyttöä, mutta kaikkia tutkimustuloksia ei kuitenkaan hyväksytä. Retorisen strategian toinen vaihe onkin esitetyn näytön leimaaminen.

Esitetyn näytön leimaamiseen liittyy monia aspekteja. Ensinnäkin, jos yksi osapuoli esittää näyttöä väitteensä tueksi, pyrkii vastassa oleva episteeminen yhteisö usein vähättelemään esitetyn näytön relevanssia. Esimerkiksi näin:

"Ongelmallinen artikkeli. Väärinymmärtää konseptin 'teoria'."

Toiseksi keskusteluissa vedotaan usein tutkimustuloksiin, joihin episteemisen yhteisön ulkopuolisilla ei ole pääsyä. Tämä saavuttamattomuus on usein konkreettista: tieteelliset artikkelit ovat usein maksumuurin takana. Tämä tarkoittaa, että keskustelija voi helposti kirjoittaa mitä vaan, kun faktantarkastajia ei ole välttämättä heti paikalla.

Kolmanneksi näissä yhteyksissä kritisoidaan usein hyvin tiukasti sinänsä päteviä akateemisia tutkimustuloksia tai niiden esittäjiä:

"No nuo ei ole taloustieteen lehtiä. Ks. lista jonka laitoin."

"Huomasitko mitä X löysi viitteestä? Ei ihme jos on pihalla jos lukee noin huonoja journaleja"

"Kaverilla ei ole yhtään julkaisua oikeassa taloustieteen lehdessä ja pitäisi olla huippu."

Tämä retorinen strategia kohdistetaan toistuvasti erityisesti heterodoksisiin taloustutkijoihin. Strategiana on todeta, että haastateltavalla on omituiset 
näkemykset, korostaa julkaisujen puutetta "oikeissa lehdissä", ja kieltäytyä keskustelemasta kritiikistä tältä pohjalta. Puheena olevan tutkijan asiantuntemus voidaan näin kieltää tai jopa asettaa naurunalaiseksi.

Vaikka nämä keskustelut on käyty Twitterissä, on kiinnostavaa huomata, että keskusteluun osallistuvat taloustieteilijät näyttävät ajattelevan tieteen konsensuksen esittävän "oikeat" tavat ajatella taloudesta. Tämä näkyy esimerkiksi keskustelussa Vasemmistoliiton talous- ja veropolitiikassa:

Taloustieteilijä: "Täällä seikkailevat taas "monet taloustieteilijät". Mainitse nyt muutama samanlaisen verotuksen ystävä."

Politiikko: "...namedrop ei kuitenkaan ollut pointti, vaan valheellinen tapa väittää edustavasi taloustieteellistä konsensusta."

Taloustieteilijä: "Aika synkeäksi menee kun valehtelusta aletaan puhua. Minusta Mirrlees-raportti edustaa konsensusta."

Poliitikko: "Älä siirrä maalia. Väität edustavasi konsensusta kaikessa muussakin, mm. elvytyksen vastustamisessa."

Taloustieteilijä: "Käsitellään meikäläisen muita valheita vaikka kohta. Mutta sinusta Mirrlees-raportti ei edusta konsensusta?"

Sama ilmiö näkyy koulutuskeskustelussa:

"[Hän] esitti taloustieteen konsensusnäkemyksen blogissa. Ei tarvita viitteitä."

Seuraava dialogipätkä esiintyy perhevapaita koskevassa keskustelussa:

Taloustieteilijä: "Ja nykyisen tasoisen vanhempainvapaan puolustaminen, tai väite että kartellisoituminen lisää hyvinvointia, poikkeavat suuresti standardiajattelusta." [kaksi twiittiä yhdistetty]

Puhuja 1: "Mistä mä tiedän mitä standardiajattelu sanoo mistäkin?" 
Taloustieteilijä: "Taloustieteen oppikirjasta vaikka."

Äänessä olevan taloustieteilijän mukaan "standardiajattelusta" poikkeava edustaa joko tieteellisesti tai poliittisesti "väärää". Tämän yhteydessä, kuten myös ylempänä taloustieteen konsensukseen viitatessa, väitetään taloustieteen perusoppikirjoissa olevan yhteiskunnallisten ongelmien ymmärtämiseen tarvittava "oikea" viisaus.

Yllä kuvattu retorinen strategia on hyvä esimerkki me-he-jaottelun tekemisestä. Tästä syystä epäsymmetrinen näytön vaatiminen retorisena strategiana on tärkein havaitsemistamme strategioista: jotta voi puhua asiantuntijuudesta, pitää ensin määrittää, kuka sen piiriin kuuluu. "Näytön vaatiminen” on oiva strategia tämän tekemiseksi, koska se tuo selkeästi esiin rajan asiantuntijoiden ja ei-asiantuntijoiden välillä. Sisäryhmä määrittää normit, joiden perusteella sisäryhmään saa kuulua. ${ }^{4}$ Keskeinen kriteeri näyttää olevan uskollisuus tietyille oppikirjoille ja laajemmin "objektivistinen" tiedonkäsitys (Muis 2007).

\section{Auktoriteetin kiistäminen}

Toinen aineistosta ilmenevä retorinen strategia on auktoriteetin kiistäminen. Sen funktio on selkeä: toisen keskustelijan väitteen mitätöinti väitteen esittäjän mitätöimällä. Tämä strategia oli aineistossa esillä erityisesti Laura Lindstedtin Finlandia-puheen jälkeen. Se näkyi usein myös keskustelussa koulutuksen maksullisuudesta. Tyypillisesti keskustelut ovat taloustieteilijöiden ja ei-taloustieteilijöiden välisiä.

"Sulla ei tunnu olevan mitenkään hirveän kirkas näkemys siitä, mitä taloustiede tutkii ja miten."

"Et ilmeisesti ymmärrä vedonlyönnin käsitettä kovin hyvin."

"Kuulostaa syvälliseltä, mitä on 'talous'?"

Edellä esiin nostetut twiitit kuvaavat hyvin, miten ei-taloustieteilijöille puhutaan. Ensimmäinen twiitti esiintyi jo aiemmin mainitussa keskustelussa kuluttajan haluista. Keskustelussa toinen osapuoli yrittää kritisoida taloustieteen 
näkemystä rationaalisuudesta ja toinen osapuoli (kaksi henkilöä) yrittää siirtää keskustelua pois tästä aiheesta. Yksi retorinen strategia keskustelussa on kyseenalaistaa toisen keskustelijan talousosaamista viittaamalla siihen, että hän ei tiedä mitä ja miten taloustiede tutkii. Edellä esitetyistä toinen twiitti voidaan tulkita olevan humoristinen ja kolmas twiitti joko huumoria tai sarkasmia. Niiden funktiona on osoittaa, että toinen puhuja ei tiedä, mistä hän puhuu, mutta samalla implikoida, että twiitin kirjoittaja kyllä tietää.

"Taloustiede tuskin voi ottaa vastuuta siitä että joku amatööri vetoaa"

"Keskustelu oli yleinen. Sekavia puhui. Kirja huono. Arvostus 0."

Edellisistä ensimmäinen twiitti viittaa siihen, että yksi keskustelija referoi Yle A-studion puheenvuoroa, jossa toistettiin TINA-argumenttia eli tietyn talouspolitiikan vaihtoehdottomuutta. Toinen keskustelija vastaa twiitin mukaisesti eli implikoi, että jos toinen (ei-taloustieteilijä) käyttää argumentteja taloustieteestä, se ei siltikään tarkoita, että taloustiede olisi poliittinen tiede. Tämänkin twiitin funktiona on osoittaa, että ei ole luottamista keneenkään muuhun kuin "oikeisiin" asiantuntijoihin. Jälkimmäinen twiitti on nostettu keskustelusta, jossa puhutaan avoimesti siitä, kuka on taloustieteen asiantuntija. Heterodoksista suuntausta edustava professori yrittää keskustella siitä, että maailmassa monta "suurta nimeä" jotka eivät hyväksy edellä mainittuja konsensusnäkemyksiä taloustieteestä. Tällä tavalla, yhdellä twiitillä, pyritään mitätöimään tunnetuidenkin eri koulukuntaa edustavien taloustutkijoiden auktoriteettia.

\section{Kaksoisstandardi}

Kaksoisstandardin keskustelustrategia viittaa siihen, että taloustieteilijät katsovat voivansa kommentoida lähes mitä tahansa aihetta (nojaten mahdollisesti siihen, että analyysi on "oppikirjatason materiaalia") mutta muilta tutkijoilta/asiantuntijoilta vaaditaan perehtymistä taloustieteeseen voidakseen 
osallistua keskusteluun. Esimerkiksi voidaan nostaa seuraava twiitti:

"Minusta on ihan ok tiedustella järjestöissä koko elämänsä työskenneeltä tämän yritystietouden perustaa."

Kommentti julkaistiin Twitterissä televisiodebatin jälkeen, missä Hjallis Harkimo haastoi vasemmistopoliitikko Li Anderssonia kertomaan, kuinka monta yritystä hän on perustanut. Kommentin kirjoittaja vastasi saamaansa kritiikkiin näin:

"Jos minä alan jossakin vaiheessa kertoa miten oopperaa pitää laulaa, saatte kysyä että mistä tiedän.”

Toinen esimerkki:

"Oletko varma että tunnet asian niin hyvin että pystyt tuollaisen arvion esittämään?"

Edellinen twiitti on kommentti tunnetulta taloustieteilijältä ihmiselle, joka on Twitter-profilinsa mukaan start-up yrityksen johtaja ja kokenut kaikenlaisista digitaalisista työkaluista. Hän kritisoi taloustieteen metodologiaa siitä, että se "vaikuttaa itseriittoiselta." Eräs taloudellisen tutkimuslaitoksen tutkija jatkaa kysymykseen auktoriteettiuskosta: "Siitä, etten usko amatöörejä, ei voi päätellä, että uskoisin auktoriteetteja.” Twiitistä jää epäselväksi, keitä kyseiset amatöörit ovat, mutta keskustelun jatkosta voi päätellä, että nämä ovat taloustieteen toisten koulukuntien edustajia. Eräs taloustieteilijä viittaa eri koulukuntaa edustavan taloustutkijan kirjaan:

"Samalla itseriittoisuudella kiistät leipätekstisi lukemattomat heikkoudet"

Vaikka kyseinen keskusteluketju rönsyilee ja saa nettikiusaamisen piirteitä, on sen ilmeinen funktio esittää oikeille oppikirjoille uskollisuutta 
tunnustamattomat taloustieteilijät amatööreinä.

"Ei ole mustam. vaan sen toteamista että mikroskooppinen kirjallisuus 3. luokan journalissa ei edusta tiedettä."

Keskustelussa on kyse siitä, tarvitaanko Suomessa palkanalennuksia. Puhuja vetoaa Cambridge Journal of Economics -lehteen, jossa on julkaistu runsaasti tutkimusta palkkavetoista kasvusta. Tähän taloustieteilijä vastaa:

"Minusta teidän kannattaa tutustua perusasioihin ennen kuin alatte lukea journaleja http://www.sciencedirect.com/science/handbooks/15734463 ..."

Tiivistetystä keskustelusta tulee selkeästi esiin joidenkin suomalaisten taloustieteilijöiden haluttomuus ottaa vakavasti heidän näkökulmastaan poikkeavaa taloustiedettä sekä yhteisön suljettu metodologinen ote. Samoin kommentista ilmenee, että sen kirjoittaja mittaa tietyn alan totuudellisuutta sen mukaan, kuinka paljon siihen liittyy kirjallisuutta. Myös tutkimuksen julkaisu on tässä ajattelussa ratkaisevaa sen kannalta, onko kyseinen tutkimus "tiedettä" vai ei. Tässä yhteydessä on syytä muistaa, että juuri taloustieteen lehtien julkaisupolitiikka on metodologisesti ja teoreettisesti hyvin ulossulkevaa. Esimerkkinä voidaan pitää tiettyjen maineikkaiden taloustieteen lehtien, kuten American Economic Review'n, tapaa suosivia tiettyjä matemaattisen mallintamisen menetelmiä yli muiden.

Myös keskustelussa koulutusmaksuista ilmenee hyvin selvästi kaksoisstandardien käyttö. Koska retorinen strategia ei tässä(kään) ilmene suoraan yhdestä twiitistä, lainaamme keskustelua pidemmin:

Taloustieteilijä: "Kaikki minun kirjoituksessani olevat asiat ovat oppikirjatason kamaa, jonka kaikki ekonomistit tietävät.”

Taloustieteilijä: "Ja lähdeviitteeksi riittää tässä tapauksessa mikä tahansa koulutuksen taloustieteen oppikirja / käsikirja” 
Humanisti: "Ihan mistä vaan taloustieteen oppikirjasta löytyy tälle väitteelle tuki? [että koulutusmaksu olisi hyvä asia]"

Taloustieteilijä: "Ihan mistä tahansa oppikirjasta, jossa asiaa käsitellään. Kyllä.”

Humanisti: "Jos kopo [koulutuspolitiikka] kiinnostaa, teettekö jotain RUSEn kanssa, ne osais niinQ tutkiakin näitä juttuja.]

Taloustieteilijä: "Sinä et tunne alan tutkimusta lainkaan, et tunne alan oppikirjateoriaa, ja neuvot muita miten pitäisi ajatella."

Humanisti: "Eikö kirjoituksesi tarkoitus ollut provosoida keskustelua? Ja nyt keskustelu ei kelpaakaan?"

Taloustieteilijä: "Se, että inttää omaa epätieteellistä näkemystään ilman perusteluja, ei ole kiinnostavaa keskustelua."

Humanisti: "En intä, perustelen huolellisesti. Mutta en ole taloustieteilijä, se on kyl melkonen rikos.”

Humanisti oli esittänyt blogissaan kritiikkiä koulutusmaksuja kohtaan. Blogissa oli esillä argumentin lisäksi tukea väitteisiin linkkien kautta. Nämä linkit viittasivat lehtiartikkeleihin, joissa tutkimusta käsiteltiin. Blogiartikkelissa lainauksessa keskustelevan taloustietelijän blogiteksiä kritisoitiin lähteettömyydestä. Kaksoisstandardi tarkoittaa tässä tapauksessa sitä, että taloustieteilijät katsovat voivansa kirjoittaa ilman lähdeviitteitä, mutta muilta vaaditaan jatkuvasti viitteitä, vaikka niitä olisi annettu. Tämä retorinen strategia esiintyy usein edellä käsitellyn näytön vaatimisen yhteydessä.

Kaiken kaikkiaan tunnistamamme kolme retorista strategiaa ajavat samaa päämäärää: asiantuntijuuden piirin rajaamista. Tämä tapahtuu vähintään osoittamalla joku muu kuin taloustieteilijä joukkoon kuulumattomaksi. Pahimmillaan keskustelua ajetaan kysymyksiin, joilla ei ole enää mitään tekemistä alkuperäisen aiheen kanssa. Esimerkiksi harhaanjohtavan virheen strategia on helppo havaita, mutta siitä on vaikeaa päästä takaisin alkuperäiseen 
keskusteluun. Kolme tunnistamaamme strategiaa osoittavat, että sosiaalisessa mediassa käydään voimakasta ulkotieteellistä asiantuntijuuskamppailua. Vaikka toisinaan nähdään myös argumentatiivisempaa keskustelua, näitä strategioita näytetään käytettävän silloin, kun joka ulkoryhmästä haastaa jollain tavalla sisäryhmän asemaa. Tämän aineiston perusteella ei tietenkään voi päätellä muusta kuin mitä keskusteluihin osallistujat itse kirjoittivat, mutta näyttää siltä, että heidän näkemyksensä mukaan taloustiede esittää jonkinlaisen episteemisen totuuden:

Puhuja 1: "Onko sitten muiden yhtk tieteenalojen oppimisessa sama juttu? Miltä pohjalta esität kritiikkisi?"

Taloustieteilijä: "Ihan tavanomainen tilastotieteen ja ekonometrian menetelmäkoulutus.”

\section{Johtopäätöksiä}

Vaikka kaikkien tieteenalojen piirissä esiintyy tieteenalan identiteetin hakemista ja demarkaatiokeskusteluja, on taloustiede erityisen intensiivinen kamppailujen kenttä. Siinä korostuvat yleisen asiantuntija-aseman ja tiettyjen "oppikirjojen" eli metodologisen perustan yhteisöllinen puolustaminen. Olemme tässä artikkelissa käyneet läpi yhden "tilapäisen julkisuuden" alueella tapahtuvaa neuvottelua talousasiantuntijuudesta ja talousasiantuntijuuden rajojen vetämistä. Lähtökohtana on ollut tulkinta taloustietelijöistä episteemisenä yhteisönä ja retoristen strategioiden tutkimus. Analyysissa tämän episteemisen yhteisön, jonka yhteiskunnallinen vaikutusvalta on riippuvaista tietystä tieteellistä näyttöä "edeltävästä" auktoriteettiasemasta, havaittiin puolustautuvan nimenomaan yhteisönä.

Aineistosta hahmottuu kolme retorista päästrategiaa: epäsymmetrinen näytön vaatiminen, auktoriteetin kieltäminen ja kaksoisstandardi. Osittain strategiat ovat päällekkäisiä. Niitä voidaan kuitenkin analysoida erillisinä strategioina sen osoittamiseksi, minkälaisin retorisin keinoin talousasiantuntijuus suojelee itseään maaperällä, jossa tästä käydään selvimmin kamppailua: sosiaalisessa mediassa. Nämä strategiat eivät sellaisenaan toimisikaan 
perinteisillä asiantuntijakamppailun areenoilla eli muodollisen tieteellisen keskustelun parissa. Kaiken kaikkiaan nämä kolme retorista strategiaa ajavat asiantuntijuuden piirin rajaamista. Keskusteluissa usein vedotaan tieteellisiin asiantuntijuuskriteereihin, kuten akateemisissa journaaleissa julkaisemiseen, mutta keskusteluiden pyrkimys ei palaudu formaalien kriteerien soveltamiseen. Keskustelustrategioita on mielekkäintä tutkia ulkotieteellisinä, retorisina, yhteisöllisinä ja konstruktiivisina. Strategioissa keskeistä ovatkin retoriset keinot, eivät niinkään akateemiset taustat (kuten "cv"). Some-julkisuus on tässä mielessä muodoltaan selkeämmin "poliittista" erotuksena "tieteellisestä".

Toki voidaan kysyä, millaista yleistä yhteiskunnallista merkitystä Twitter-keskusteluilla on. Tämän tutkimuksen näkökulmasta riittää todeta, että niillä on selvä episteemisen yhteisön itsepuolustusrooli. Voidaan tulkita, että some-keskustelut toimivat jonkinlaisena talousasiantuntijuuden puolustamisen "lattiatasona". Niiden voidaan olettaa vaikuttavan muuhun julkisuuteen ja luovan agendaa perinteisemmän julkisuuden keskusteluille. Keskustelujen muodon ja luonteen johdosta on selvää, että Twitterin keskustelut muistuttavat pikemmin julkisuutta kuin suljettua keskustelutilaa: keskustelujen muoto osoittaa niiden olevan nimenomaan episteemisen yhteisön itsepuolustukseen osallistuvaa. Näiden keskustelujen ja esimerkiksi journalistisen näkyvyyden välisen dynamiikan selvittäminen on kiinnostava jatkotutkimuksen aihe. Twitter-ainestot avaavat laajemminkin mahdollisuuksia sosiaalitieteisiin, vaikka edistys esimerkiksi määrällisen diskurssianalyysin kehittämisessä on tarvittavien ohjelmointitaitojen takia hidasta (Rinker 2013).

Yleisesti analyysimme tukee Fourcaden ym. (2015) löydöksiä taloustieteen yhteisöllisiä piirteitä koskien. Taloustieteilijöiden episteeminen yhteisö suojelee tarkastelemassamme julkisuudessa alan suljettua asemaa (insularity) ja hierarkkista asemaa suhteessa muihin yhteiskuntatieteisiin. Myös käsitys muiden yhteiskuntatieteiden tuloksiin viittaamisen tarpeettomuudesta elää keskusteluissa vahvana. Yhteiskunnallinen asema ja vaikutusvalta eivät tule suoraan esiin tekstuaalisista aineistoista, mutta kuten alussa totesimme, perustuu vaikutusvalta tiettyyn tieteen ulkoiseen auktoriteettiasemaan, jonka puolustamiseen olemme tulkinneet yllä analysoitujen keskustelujen keskittyvän. Luonnollisesti vaikutusvalta on myös ilmiö, jossa moni taso vaikuttaa toisiinsa. Taloustieteen maailmankuva muokkaa poliittisia käsityksiä ja 
politiikan ilmapiiri voi osaltaan olla otollinen taloustieteen edustajien retorisille strategioille.

\section{Viitteet}

I) Christian Arnsbergerin ja Yanis Varoufakisin mukaan uusklassinen taloustiede voidaan määritellä kolmen ominaisuuden kautta, jotka ovat metodologinen individualismi, metodologinen instrumentalismi sekä aksiomaattinen tasapaino-oletus. Metodologinen individualismi tarkoittaa, että todellisuutta tutkitaan aina selittämällä sitä yksilöiden toiminnasta käsin (valinnan motiivit, jne), eikä koskaan näitä toimintoja ehdollistavasta ja rakenteistavasta sosiaalisesta todellisuudesta. Metodologinen instrumentalismi taas tarkoittaa, että kaikki toiminta ymmärretään välineellikseksi suhteessa yksilöiden preferenssien tyydyttämiseen. Preferenssit otetaan annettuina ja ne erotetaan jyrkästi sekä uskomuksista että preferenssien tyydyttämisen välineistä. Aksiomaattinen tasapaino-oletus on taas seurausta uusklassisen taloustieteen tarpeesta tehdä makrotason ennustuksia, mikä on vaikeaa mainittujen metodologisten oletusten pohjalta. Näin tarvitaan oletus yksilöolioiden toiminnan koordinaation logiikasta, minkä vuoksi uusklassisen taloustieteen kysymykset esitetään kysymyksinä siitä, miten yksilöt toimisivat tasapainon vallitessa - kun taas kysymys siitä, miten tasapainotilat syntyvät tai ovat syntymättä, on vähemmän olennainen. (Arnsberger \& Varoufakis 2006).

2) Mirowskin ja Plehwen (2008) käyttämä "ajatusyhteisön" käsite poikkeaa "episteemisen yhteisön" käsitteestä korostamalla poliittisia pyrkimyksiä, kun taas jälkimmäinen käsite korostaa jaettua epistemologista ymmärrystä.

3) Sosiologisemmassa tutkimuksessa taloustieteen on katsottu heijastelevan esimerkiksi luokka-asemia (Aune 2001) tai porvarillisia hyveitä (McCloskey 1997). Nämä ovat epäilemättä tosia havaintoja. Tässä artikkelissa keskitymme kuitenkin episteemisiin yhteisöihin, minkä vuoksi "materiaaliset" selitykset on jätetty vähemmälle. Taloustieteen retoriikan tutkimuksesta ks. myös Klamer (1987). 
4) Rajallisen Twitter-aineistomme perusteella on mahdotonta kuvata kattavasti sisäryhmän normistoa. Voidaan kuitenkin todeta, että siihen kuuluu julkaiseminen tietyissä journaaleissa, kielteinen suhtautuminen taloustieteen metodologiakritiikkiin ja kapea näkemys hyväksyttävästä taloustutkimuksesta.

\section{Lähteet}

Alasuutari, Pertti. 2007. Laadullinen tutkimus. 3. uudistettu laitos. Tampere: Vastapaino.

Arnsberger, Christian \& Varoufakis, Yanis. 2006. What is neoclassical economics? Post-autistic economics review, 38, 2-12.

Aristoteles. 2012. Retoriikka (Teokset IX). Suomentaneet Paavo Hohti ja Päivi Myllykoski, selitykset laatinut Juha Sihvola. Helsinki: Gaudemus.

Aune, James. 2001. Selling the free market: The rhetoric of economic correctness. New York: Guilford Press.

Blyth, Mark. 2002. Great Transformations: Economic Ideas and Institutional Change in the Twentieth Century. Cambridge: Cambridge University Press.

Callon, Michel. 2010. Performativity, misfires and politics. Journal of Cultural Economy, 3:2, 163-169.

Chouliaraki, Lilie \& Fairclough, Norman. 1999. Discourse in Late Modernity: Rethinking Critical Discourse Analysis. Edinburgh: Edinburgh University Press. Chwieroth, Jeffrey. 2007. Neoliberal economists and capital account liberalization in emerging markets. International organization, 61(2), 443-463.

Cohen, Avi J. 2010. Capital controversy from Böhm-Bawerk to Bliss: Badly posed or very deep question? Or what "we" can learn from capital controversy even if you don't care who won. Journal of the History of Economic Thought, 32:1, 1-21.

Cohen, Avi J. ja Harcourt, Geoff C. 2003. Whatever Happened to the Cambridge Capital Controversies? Journal of Economic Perspectives, 17, 199-214.

Culotta, Aron. 2010. Towards detecting influenza epidemics by analyzing

Twitter messages. Proceedings of the first workshop on social media analytics, $115-122$. 
Edwards, Adam, Housley, William, Williams, Matthew, Sloan, Luke ja Williams, Malcolm. 2013. Digital social research, social media and the sociological imagination: surrogacy, augmentation and re-orientation. International Journal of Social Research Methodology, 16:3, 245-260.

Eskola, Jari ja Suoranta, Juha. 1998. Johdatus laadulliseen tutkimukseen. Tampere: Vastapaino.

Fine, Ben. 2002. Economic imperialism: a view from the periphery. Review of Radical Political Economics, 34:2, 187-201.

Foldvary, Fred. 1996. Beyond neoclassical economics: heterodox approaches to economic theory. Cheltenham: Edward Elgar.

Fourcade, Marion. 2006. The construction of a global profession: the transnationalization of economics. American journal of sociology, 112:1, 145-194.

Fourcarde, Marion, Ollion, Etienne ja Yann, Algan. 2015. The superiority of economists. Journal of economic perspectives, 29:1, 89-114.

Fraser, Nancy. 2009. Uusi katse julkisuuteen. Vallitsevan demokratian arvostelua. Media \& viestintä, 32:3, 8-30.

Haas, Peter M. 1992. Epistemic communities and international policy coordination. International organization, 46: 1, 1-35.

Hakkarainen, Kai, Palonen, Tuire, Paavola, Sami ja Lehtinen, Erno. 2004. Communities of networked expertise: Professional and educational perspectives. Amsterdam: Elsevier.

Harjuniemi, Timo; Herkman, Juha ja Ojala, Markus. 2015. Eurokriisin politisoituminen suomalaisissa sanomalehdissä. Media \& viestintä, 38:1, 1-22. Hirschman, Daniel ja Berman, Elizabeth Popp. 2014. Do economists make policies? On the political effects of economics. Socio-Economic Review, 12:4, 779-811.

Kaidesoja, Tuukka. 2016. Sosiologia, yhteiskunnalliset ongelmat ja keskitason teoriat. Sosiologia-lehden verkkoartikkeli 18.4.2016. http://www.sosiologia. fi/blog/2016/sosiologia-yhteiskunnalliset-ongelmat-ja-keskitason-teoriat/ [viitattu 30.5.2017]

Klamer, Arjo. 1987. As if economists and their subjects were rational. Teoksessa J.S. Nelson, A. Megill ja D.N. McCloskey (toim.), The rhetoric of the human sciences: Language and argument in scholarship and public affairs. Madison, WI: University of Wisconsin Press, 163-183. 
Kogut, Bruce ja Macpherson, J. Muir. 2004. The Decision to Privatize as an Economic Policy Idea: Epistemic Communities, Palace Wars and Diffusion. International Diffusion of Political and Economic Liberalization. Pariisi: INSEAD.

Kolehmainen, Marjo \& Rättilä, Tiina. 2008. Mikä politiikka? Kenen media? Tiedotustutkimus, 31:5, 1-6.

Lee, Frederic. 2009. A history of heterodox economics. Challenging the mainstream in the twentieth century. Lontoo: Routledge.

Lehtinen, Erno ja Palonen, Tuire. 2011. Asiantuntijaosaamisen luonne ja osaamisen tunnistamisen haasteet. Ammattikasvatuksen aikakauskirja, 13:4, 24-42.

MacKenzie, Donald A., Muniesa, Fabian ja Siu, Lucia (toim.). 2007. Do economists make markets? On the performativity of economics. Princeton: Princeton University Press.

McCloskey, Donald. 1998. The rhetoric of economics. 2. painos. Madison: University of Wisconsin Press.

McCloskey, Donald. 1997. The vices of economists; the virtues of the bourgeoisie. Ann Arbor: University of Michigan Press.

Mirowski, Philip ja Plehwe, Dieter (toim.). 2009. The road from Mont Pelerin: The making of the neoliberal thought collective. Cambridge, MA: Harvard University Press.

Muis, Krista. 2007. The role of epistemic beliefs in self-regulated learning. Educational Psychologist, 42:3, 170-190.

Myers, Greg. 2003. Discourse Studies of Scientific Popularization: Questioning the Boundaries. Discourse Studies, 5:2, 265-279.

Mäki, Uskali. 2009. Economics imperialism. Concept and constraints. Philosophy of the Social Sciences, 39:3, 351-380.

Nickles, Thomas. 2006. The problem of demarcation. Teoksessa Jessica Preifer \& Sahotra Sarkar (toim.), The philosophy of science. An encyclopedia. Lontoo: Routledge, 1-188.

Nik-Khan, Edward ja Van Horn, Robert. 2012. Inland empire: Economics' imperialism as an imperative of Chicago neoliberalism. Journal of economic methodology, 19: 3, 259-282.

Parviainen, Aapo. 2014. Mediassa paras ekononomisti on pankkiekonomisti. Kansantaloudellinen aikakauskirja, 110:4, 574-581.

Perelman, Chaim. 1996. Retoriikan valtakunta. Tampere: Vastapaino. 
Raatikainen, Panu. 2004. Ihmistieteet ja filosofia. Helsinki: Gaudeamus.

Rinker, Tyler W. 2013. qdap: Quantitative Discourse Analysis Package. 2.2.5. Buffalo: University at Buffalo. http://github.com/trinker/qdap [viitattu 30.5.2017]

Scheepers, Daan, Spears, Russell, Doosje, Bertjan ja Manstead, Anthony. 2006. The social functions of ingroup bias: Creating, confirming, or changing social reality. European review of social psychology, 17:1, 359-396.

Shirky, Clay. 2011. The political power of social media. Foreign Affairs, 90:1, 28-41.

Stewart, Craig O. 2008. How a media controversy can influence a scientific publication. The case of Robert L. Spitzer's "reparative therapy" study. Teoksessa Christopher Eisenhart \& Barbara Johnstone (toim.), Rhetoric in Detail : Discourse Analyses of Rhetorical Talk and Text. Amsterdam: John Benjamins Publishing Co, 255-278.

Suvanto, Antti. 2016. Taloustietelijät sosiologien silmin. Kansantaloudellinen aikakauskirja, 112:1, 3-5

Tuomi, Jouni ja Sarajärvi, Anneli. 2002. Laadullinen tutkimus ja sisällönanalyysi. Helsinki: Tammi.

Vartiainen, Juhana. 2014. Kestävyysvaje on eettinen dilemma. Tieteessä tapahtuu, 32:3, 34-36.

Vähämaa, Miika. 2015. Ryhmät episteemisinä toimjoina. Ryhmien asema validin tiedon tuottajina. Media \& Viestintä, 38:3, 204-211.

Vähämaa, Miika ja West, Mark D. 2014. The dilemma of group membership in the internet age. Public knowledge as preferred misinformation. Javnost the public. Journal of the European institute for communication and culture. 21:1, 5-18.

Yardi, Sarita ja boyd, danah. 2010. Dynamic debates: An analysis of group polarization over time on Twitter. Bulletin of Science, Technology \& Society, 30:5, 316-327. 